\title{
PREFACE AND ACKNOWLEDGMENTS
}

The present volume is intended to give a concise general introduction in English to the Etruscan remains at the ancient community of Cetamura del Chianti (Siena) in Italy. The main focus, within the University of Texas Press series on the Cities and Communities of the Etruscans, is to demonstrate that a settlement such as Cetamura can provide novel perspectives on society, economy, religion, industry, and other cultural aspects in an Etruscan rural context that appears to be very different from what we see at major Etruscan urban sites like Caere and Veii.

A much-abbreviated version of this text was first published in Italian as Cetamura del Chianti: Una communità etrusca (Florence: Edifir, 2017), in connection with an exhibition at the Museo Archeologico Nazionale di Firenze (MAF), "I pozzi delle meraviglie: Nuove scoperte a Cetamura del Chianti," on display from June 9 to September 30, 2017. That Italian text was conceived as a complement to the exhibition catalog in English, Wells of Wonders: New Discoveries at Cetamura del Chianti (Florence: Edifir, 2017).

I am grateful to Edifir for allowing the University of Texas Press to incorporate content from the version originally published in Italian. Scholarly research is here presented with great attention to details and documentation in endnotes, resulting in a different kind of research contextualization that matches closely what has been presented as ideal in the University of Texas Press volumes on the Etruscan cities of Caere and Veii. 
It is truly impossible to thank properly the many individuals who contributed to the presentation of material in this volume. The principal researchers are recognized in chapter 8, "Cetamura after Antiquity," and I know I speak for all members of the team in expressing gratitude to the Italian entities and administrators that have unfailingly supported our efforts: the Ministero dei Beni e delle Attività Culturali of the state of Italy and its wing for archaeology, the Soprintendenza Archeologia Belle Arti e Paesaggio (SABAP) per le province di Siena, Grosseto e Arezzo (Arch. Anna Di Bene, Soprintendente), along with Florida State University (Tallahassee, Florida), especially the entity of International Programs (Jim Pitts, Director) and Studio Arts College International in Florence (SACI; Steven Brittan, President). We acknowledge the encouragement and enthusiasm of the Badia a Coltibuono and the Comune of Gaiole in Chianti (SI), within the territory of which Cetamura is located, and important financial support from the Consorzio Vino Chianti Classico, which has helped with urgently important research on the ancient grape seeds found in the wells of Cetamura. It is a pleasure to thank here the many individual donors who have supported the research and contributed toward the successful exhibition.

Several individual names cannot be omitted from the acknowledgments. Most recently, Frank Nero, Director of the Florida State University Study Abroad Program in Florence, with the encouragement of the US Consul General to Florence, Benjamin V. Wohlauer, has renewed the commitment of the study center to the Cetamura project, which began originally in 1973 as a course in the FSU Florence program and in 1978 became an independent summer field school. The resources of the superb staff, facilities, and student body of the study center have been of the greatest value for a new agenda involving the creation of a museum for Cetamura. Michele Pescini, the mayor of Gaiole in Chianti, has been an ardent supporter of the excavations and with the town council of Gaiole has recently designated space for a museum for Cetamura and the origins of Chianti in the handsome restored building of the former Cantine Ricasoli in the center of Gaiole, now named the Museo Civico Alle Origini del Chianti. 
Mario Iozzo, Director of the Museo Archeologico Nazionale di Firenze, validated the importance of the material remains of Cetamura by welcoming the exhibition of "I pozzi delle meraviglie" to the museum. Pierluigi Giroldini, formerly funzionario from SABAP for Cetamura, constantly assisted with every kind of problem faced; Jacopo Tabolli now serves as funzionario in the same role with no less enthusiasm and effectiveness. He has been a dedicated ally in following the procedures associated with the creation of the museum. Nòra Marosi of SACI performed an enormous service to Cetamura and to ancient archaeology by her diligent labors in conserving and restoring a wide range of objects from the site, and by locating and contacting experts who could assist in numerous ways with the special needs of the Cetamura research. She "discovered" the firm of Ichnos: Archeologia, Ambiente e Sperimentazione at Montelupo Fiorentino (Francesco Cini, President), which carried out the arduous excavations in two wells at Cetamura, and established contact with our principal artist, Rosalba Settesoldi, who has created hundreds of drawings of artifacts from Cetamura, some of which are featured in this volume. Many of the photographs of artifacts included here were made by Professor Ken Kobre, a graduate of Florida State University who attended the FSU Study Center at Florence in 1966 at the time of the great flood and who offered his services gratis for the catalogue and this book. Peter Krafft, formerly of FSU, has created all of the final site maps since 1983. Kaitlin Rizzo, a recent graduate of FSU and program assistant for both the Florence and Cetamura programs, took care of final tasks in photography.

Giovanna Bagnasco Gianni, Director of excavations at the major Etruscan city site of Tarquinia, has never failed to show interest in the community site of Cetamura and to contribute when asked to the interpretation of the research. Without her collaboration, my own understanding of the site would be greatly limited. 